\title{
DISPENSASI PERNIKAHAN DI BAWAH UMUR PADA MASYARAKAT ISLAM DI KABUPATEN BANTAENG
}

\author{
Nur Aisyah \\ Universitas Islam Negeri (UIN) Makassar \\ Email : aisyahuin@gmail.com
}

\begin{abstract}
The fuqoha and lawyers agree that a person is held accountable for his actions and has the freedom of determining his life after his age (Baligh). With reference to applicable legislation, if the prospective bride is under 16 years of age and the prospective bridegroom under the age of 19 years, then the person is categorized as underage and incompetent to act in the law in the case of marriage . several factors that cause the proposed marriage dispensation, among others, due to Pregnant Factor before marriage, Economic Factors, and Factors Education. Judge consideration in granting judgment of marriage age is the judge not only raced on the Act, this is where the ijtihad judge is needed in determining something based on mursalah maslahat.
\end{abstract}

Keywords: Wedding Dispensation

\begin{abstract}
Abstrak
Para fuqoha dan ahli undang- undang sepakat menetapkan, seseorang diminta pertanggungjawaban atas perbuatannya dan mempunyai kebebasan menentukan hidupnya setelah cukup umur (Baligh). Dengan mengacu pada perundang-undangan yang berlaku, jika pihak calon mempelai wanita di bawah umur 16 tahun dan calon mempelai laki-laki dibawah umur 19 tahun, maka yang bersangkutan dikategorikan masih di bawah umur dan tidak cakap untuk bertindak di dalam hukum termaksud dalam melakukan perkawinan. beberapa faktor yang menjadi penyebab diajukan dispensasi perkawinan antara lain karena Faktor Hamil sebelum melangsungkan perkawinan, Faktor Ekonomi, dan Faktor Pendidikan. Dasar pertimbangan hakim dalam mengabulkan dipensasi usia perkawinan yaitu hakim tidak hanya berpacu pada Undang - Undang, disinilah diperlukan ijtihad hakim dalam menetapkan sesuatu berdasarkan maslahat mursalah.
\end{abstract}

Kata kunci : Dispensasi Pernikahan 


\section{PENDAHULUAN}

$\mathrm{P}$

erkawinan adalah ikatan antara seorang laki-laki dan wali seorang wanita atau yang mewakili mereka dan dibolehkan bagi laki-laki dan wanita bersenang- senang sesuai dengan jalan yang telah disyariatkan. ${ }^{1}$ Allah swt telah mensyariatkan perkawinan dengan tujuan agar tercipta hubungan yang harmonis dan batasan-batasan hubungan antara mereka. Tidak mungkin bagi seorang wanita untuk merasa tidak butuh kepada seorang laki-laki yang mendampinginya secara sah meskipun dia memiliki kedudukan yang tinggi, harta melimpah ruah, atau intelektualitas yang tinggi. Begitu juga seorang laki-laki, tidak mungkin merasa tidak membutuhkan seorang istri yang mendampinginya. ${ }^{2}$

Keberadaan pernikahan itu sejalan dengan lahirnya manusia diatas bumi dan merupakan fitrah manusia yang diberikan Allah swt terhadap hamba-Nya, di antara firman Allah dalam QS.al-Nuur/24: 32.

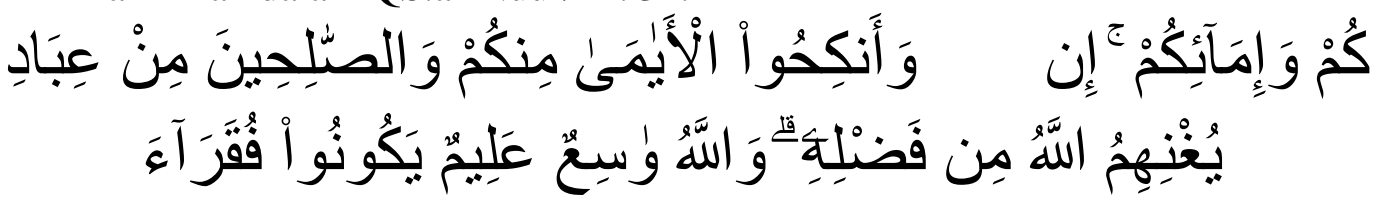

Terjemahnya :

dan nikahkanlah orang-orang yang masih membujang diantara kamu, dan juga orang-orang yang layak (menikah) dari hamba-hamba sahayamu yang laki-laki dan perempuan. Jika mereka miskin, Allah akan memberi kemampuan kepada mereka dengan karunia-Nya. Dan Allah Maha luas (pemberian-Nya), Maha mengetahui. ${ }^{3}$

Pasal 7 ayat (1) Undang-undang Perkawinan No.1 tahun 1974 jo pasal 15 ayat (1) Kompilasi Hukum Islam menyatakan bahwa perkawinan hanya diizinkan jika pria sudah mencapai umur 19 tahun dan pihak wanita sudah mencapai umur 16 tahun. ${ }^{4}$ Pernikahan untuk usia muda yang di bawah ketentuan peraturan perundang-undangan memang dibolehkan demi kemaslahatan. Secara metodologis, langkah penentuan usia kawin didasarkan kepada metode maslaha mursalah. Namun demikian, karena sifatnya yang ijtihad, yang kebenarannya relatif, ketentuan tersebut tidak bersifat kaku. Artinya, apabila

\footnotetext{
${ }^{1}$ Musfir Aj-Jahrani, Poligami dari Berbagai Persepsi (Jakarta: Gema Insani Press, 2002 ), h. 5 .

${ }^{2}$ Musfir Aj-Jahrani, Poligami dari Berbagai Persepsi, h. 13.

${ }^{3}$ Departemen Agama,RI, Alqur'an dan Terjemahnya, h. 494.

4 Lihat, Undang-Undang Perkawinan \& Kompilasi Hukum Islam di Indonesia
} (Jakarta: Direktorat Jendral Pembinaan Kelembagaan Agama Islam, 1998/1999). 
karena sesuatu dan lain hal perkawinan dari mereka yang usianya dibawah 21 tahun atau sekurang-kurangnya 19 tahun untuk pria dan 16 tahun untuk wanita, undang-undang tetap memberi jalan keluar. Pasal 7 ayat (2) menegaskan bahwa dalam hal penyimpangan terhadap ayat (1) pasal ini dapat meminta dispensasi nikah. Dalam hal siapa yang akan memberikan pengecualian atau dispensasi, maka dikeluarkanlan Undang-undang No. 1 Tahun 1974 ayat (2) yakni dalam hal penyimpangan terhadap ayat (1) pasal ini dapat meminta dispensasi kepada Pengadilan atau pejabat lain yang ditunjuk oleh kedua orang tua pihak pria maupun pihak wanita. ${ }^{5}$

Dalam UU No. 1 Tahun 1974 tentang Perkawinan, ditetapkan mampu fisik bagi perempuan berusia 16 tahun. Menurut pengalaman perempuan yang kawin dalam usia yang sangat muda akan menghadapi resiko pada saat melahirkan. Kemampuan fisik bagi pria adalah berusia 19 tahun karena pada usia itu ia dianggap telah matang untuk berumah tangga. Pada usia itu besar kemungkinan mendapat kerja dan memperoleh penghasilan, karena suami dalam islam berkewajiban memberi nafkah dan tempat tonggal kepada istri dan anak keturunannya.

Fenomena kawin muda ini tampaknya merupakan "mode" yang terulang. Dahulu, kawin muda dianggap lumrah. Tahun berganti banyak yang menentang perkawinan diusia dini. Penomena tersebut kembali lagi, kalau dulu orang tua ingin anaknya menikah muda dengan berbagai alasan malah kini banyak remaja sendiri yang bercita-cita kawin muda. Selain itu, beberapa remaja berpandangan menikah muda merupakan pilihan agar mereka terhindar dari melakukan perbuatan dosa, seperti hubungan seks sebelum menikah misalnya. Pada kenyataannya, kematangan seseorang banyak juga bergantung pada perkembangan emosi, latar belakang pendidikan, sosial, dan sebagainya.

Suatu pernikahan adalah hal yang diperintahkan oleh Allah dan Rasul, di dalamnya terdapat hikmah antara lain dapat mendatangkan ketenangan batin dan mencegah orang berbuat maksiat. Perkawinan usia muda dalam Islam pada dasarnya tidak dilarang sepanjang dapat mendatangkan kemaslahatan, hal ini dicontohkan oleh Rasulullah ketika menikahi Aisyah Binti Abu Bakar, ukurannya adalah kemampuan memenuhi kebutuhan standar suatu perkawinan, baik dari segi materi maupun dari segi kemampuan menjaga kehormatan dan keutuhan rumah tangga.

${ }^{5}$ Ahmad Rofiq, M.A, Hukum Islam di Indonesia (Jakarta: PT. Raja Grafindo Persada, 1998), h. 78. 
Pengadilan Agama Bantaeng sebagai bagian atau perpanjangan tangan Mahkamah Agung yang bertugas menerima, memeriksa, dan mengadili perkara- perkara tertentu, dalam menangani masalah dispensasi nikah tetap mengacu pada proses dan prosedur perundang-undangan yang berlaku. Melihat penomena yang terjadi di masyarakat dari tahun ke tahun semakin banyak remaja yang ingin menikah muda dan mengajukan permohonan dispensasi kawin di Pengadilan agama. Oleh karena itu, masalah dispensasi nikah perlu mendapat perhatian khusus untuk menghindari hal-hal yang tidak diinginkan dan dalam rangka penegakan hukum.

\section{PEMBAHASAN}

\section{A. Prosedur Pelaksanaan Dispensasi Terhadap Pernikahan Usia Muda Di Pengadilan Agama Bantaeng}

Dispensasi nikah diperlukan bagi calon pengantin pria yang belum berumur 19 tahun dan calon pengantin wanita belum berumur 16 tahun. Sebagaimana ditentukan dalam undang-undang: ${ }^{6}$ Perkawinan hanya diizinkan jika pihak pria mencapai umur 19 tahun dan pihak wanita sudah mencapai umur 16 tahun (UU No.1/1974 pasal 7(1)) Dalam hal penyimpangan terhadap ayat (1) pasal ini dapat meminta dispensasi kepada pengadilan atau pejabat lain, yang ditunjuk oleh kedua orang tua pihak pria maupun pihak wanita (UU No.1/1974 pasal 7(2). Selanjutnya dalam pelaksanaan teknis ketentuan UU itu, dalam permenag No.3 tahun 1975 ditentukan;

Dispensasi Pengadilan Agama, adalah penetapan yang berupa dispensasi untuk calon suami yang belum mencapai umur 19 tahun dan atau calon istri yang belum mencapaI umur 16 tahun yang dikeluarkan oleh Pengadilan Agama. (permenag No.3/1975 pasal 1(2) sub g) Apabila seorang calon suami belum mencapai umur 19 tahun dan calon istri belum mencapai umur 16 tahun hendak melangsungkan pernikahan harus mendapat dispensasi dari Pengadilan Agama; (permenag No.3/1975 pasal 13(1).

Permohonan dispensasi nikah bagi mereka tersebut pada ayat (1) pasal ini, diajukan oleh orang tua pria mupun wanita kepada pengadilan agama yang mewilayahi tempat tinggalnya; (permenag No.3/1975 pasal 13(2). Pengadilan Agama setelah memeriksa dalam persidangan, dan berkeyakinan

${ }^{6}$ Ahmad Azhar Basyir, Hukum Perkawinan Islam (Yogyakarta: Fakultas Hukum UII, 1977), h. 16 . 
bahwa terdapat hal-hal yang memungkinkan untuk memberikan dispensasi tersebut, maka Pengadilan Agama memberikan dispensasi nikah dengan suatu penetapan; (permenag No.3/1975 pasal13(3). Dalam hal permohonan dispensasi perkawinan ini harus dari orang tua atau wali calon pengantin, jadi bukan calon pengantin itu seperti pada permononan izin kawin bagi yang belum berumur. ${ }^{7}$ Adapun prosedur pelaksanaan dispensasi kawin di Pengadilan Agama Bantaeng sbb:

1. Meja 1

Pada tahap ini pemohon akan dibuatkan surat permohonan apabila pemohon telah melengkapi persyaratan yang telah ditetapkan sebagai syarat pengajuan dispensasi kawin. Petugas meja satu akan menaksir besarnya panjar biaya perkara dan menuliskanya pada surat kuasa untuk membayar (SKUM). Besarnya panjar biaya perkara diperkirakan harus telah mencukupi untuk menyelesaikan perkara tersebut

2. Kasir

Pemohon kemudian menghadap kepada kasir dengan menyerahkan surat permohonan dan SKUM. Kasir kemudian:

a. Menandatangani dan memberi nomor urut dan tanggal penerimaan perkara dalam SKUM dan dalam surat permohonan.

b. Mengembalikan surat permohonan dan SKUM kepada Pemohon sebagai dasar penyetoran panjar biaya ke Bank.

c. Setelah pemohon membayar panjar perkara kasir memberi tanda lunas dalam SKUM dan menyerahkan kembali pada pemohon.

3. Meja II

Pemohon kemudian menghadap pada Meja II dengan menyerahkan surat permohonan dan SKUM yang telah dibayar.

Kemudian Meja II:

Memberi nomor pada surat permohonan sesuai dengan nomor yang diberikan oleh Kasir. Sebagai tanda telah terdaftar maka petugas Meja II membubuhkan paraf Menyerahkan satu lembar surat permohonan yang telah terdaftar bersama satu helai SKUM kepada pemohon. ${ }^{8}$

${ }^{7}$ Anwar Sitompul, Kewenangan Dan Tata Cara Berperkara Di Pengadilan Agama (Bandung

: Armico), h 65

8 10 Mukti Arto, Praktek Perkara Perdata Pada Pengadilan Agama, ( Yogyakarta : Pustaka 
Proses penyelesaian perkara permohonan dispensasi kawin di Pengadilan Agama, Ketua Majelis Hakim setelah menerima berkas perkara, bersama-sama hakim anggotanya mempelajari berkas perkara. Kemudian menetapkan hari dan tanggal serta jam kapan perkara itu disidangkan serta memerintahkan agar para pihak dipanggil untuk datang menghadap pada hari, tanggal, dan jam yang telah ditentukan. Kepada para pihak diberitahukan pula bahwa mereka dapat mempersiapkan bukti- bukti yang diajukan dalam persidangan.

Setelah persidangan dibuka dan dinyatakan terbuka untuk umum oleh Ketua Majelis, maka para pihak berperkara dipanggil ke ruang persidangan. Kemudian ketua majelis membacakan surat permohonan pemohon yang telah didaftarkan di kepaniteraan pengadilan agama. Selanjutnya ketua majelis memulai pemeriksaan dengan pertanyaan pertanyaan yang diajukan kepada pemohon, anak pemohon dan calon anak pemohon secara bergantian. Kemudian Ketua Majelis melanjutkan pemeriksaan bukti surat, dan pemohon menyerahkan bukti surat:

1. Foto copy surat kelahiran atas nama anak pemohon yang dikeluarkan oleh kepala desa atau kelurahan.

2. Surat pemberitahuan penolakan melangsungkan pernikahan Model N-9 yang dikeluarkan oleh Kantor Urusan Agama.

Selanjutnya Ketua Majelis menyatakan sidang diskors untuk musyawarah. Pemohon, anak pemohon dan calon anak pemohon diperintahkan ke luar dari ruang persidangan. Setelah musyawarah selesai, skors dicabut dan pemohon dipanggil kembali masuk ke ruang persidangan, kemudian dibacakan penetapan yang amarnya sebagai berikut mengadili.

1. Mengabulkan permohonan pemohonan.

2. Menetapkan memberi Dispensasi kepada pemohon untuk menikahkan anaknya bernama xx dengan xxx.

3. Membebankan biaya perkara sebesar Rp. ... (...) kepada pemohon.

Setelah membacakan penetapannya, Ketua Majelis menyatakan sidang ditutup. Jika pemohon tidak puas dengan penetapan hakim, pemohon 
bisa langsung kasasi, bukan banding. ${ }^{9}$ Setelah penetapannya dibacakan biasanya majelis hakim akan memberikan sedikit masukan dan pencerahan kepada para pemohon dispensasi kawin tentang dampak yang akan terjadi dari permohonannya. $^{10}$

\section{B. Faktor penyebab dan pertimbangan hakim mengabulkan} permohonan dispensasi perkawinan di Pengadilan Agama Bantaeng.

Dispensasi usia perkawinan terjadi apabila adanya permohonan dari wali salah satu pihak laki-laki dan perempuan yang belum cukup usia untuk melakukan perkawinan dalam Undang-Undang Nomor 1 Tahun 1974 tentang Perkawinan, bagi laki-laki minimal berusia 19 tahun dan bagi wanita minimal berusia 16 tahun, meminta izin ke Pengadilan Agama.

\section{Faktor-Faktor Pengajuan Dispensasi Perkawinan}

Dalam Pasal 7 ayat (2) disebutkan bahwa penyimpangan terhadap ketentuan ayat (1) mengenai batas usia minimal untuk menikah, dapat meminta dispensasi kepada Pengadilan Agama atau pejabat lain yang ditunjuk oleh kedua orang tua pihak laki- laki maupun pihak perempuan. Jadi, berdasarkan Pasal 7 ayat (2) Undang-Undang Nomor 1 Tahun 1974 tentang Perkawinan, hakim diberi kewenangan untuk mengabulkan permohonan dispensasi usia perkawinan.

Sedangkan dalam pengajuan Dispensai Perkawinan Di Pengadilan Agama Kabupaten Bantaeng disebabkan oleh beberapa faktor. Dari hasil penelitian yang dilakukan, ditemukan Beberapa Faktor yang menjadi penyebab diajukan dispensasi perkawinan.

Dalam hal ini pihak Pengadilan Agama kabupaten Bantaeng menyebutkan maraknya dispensasi umur perkawinan adalah karena Faktor Hamil sebelum melangsungkan perkawinan, Faktor Ekonomi, dan Faktor Pendidikan.Untuk lebih jelasnya penulis akan Uraikan Sebagai Berikut :

\section{a. Hamil Di Luar Nikah}

Masa remaja adalah masa transisi antara masa anak-anak dengan masa dewasa. Pada masa ini terjadi pacu tumbuh, timbul ciri-ciri seks sekunder, tercapai fertilitas dan terjadi perubahan-perubahan kognitif dan psikologis. Peristiwa yang penting semasa remaja adalah pubertas, yaitu perubahan Pembinaan

$9{ }^{11}$ Departemen Agama RI, Bahan Penyuluhan Hukum, (Jakarta: Direktorat Jendral

Kelembagaan Agama Islam, 1999/2000), h. 188

${ }^{10}$ Wawancara dengan hakim pengadilan agama kelas 2 B Bantaeng Bapaj Ruslan S.Ag. pada tanggal 21 Juli 2016 
morfologis dan fisiologis yang pesat dari masa anak-anak ke masa dewas.

Pada masa remaja, banyak remaja mengalami perubahan baik secara fisik maupun secara psikologis, sehingga mengakibatkan perubahan sikap dan tingkah laku, seperti mulai memperhatikan penampilan diri, mulai tertarik dengan lawan jenis, berusaha menarik perhatian dan muncul perasaan cinta, akan timbul dorongan seksual, yang kemudia beralasan untuk melakukan hal-hal yang dilarang oleh agama untuk melakukan hubungan intim walaupun tidak terikat perkawinan terlebih dahulu sehingga memicu melakukan hal-hal negatif yang tidak dibenarkan.

Saat ini, banyak remaja kurang mendapatkan penerangan informasi pendidikan mengenai kesehatan reproduksi. Pengetahuan remaja tentang kesehatan reproduksi masih sangat rendah. tentang masa subur dan resiko kehamilan. Sebagai akibat dari kurangnya informasi mengenai kesehatan reproduksi, resiko terjadinya kehamilan yang tidak diinginkan itu akan semakin meningkat, walaupun pada kenyataanya remaja tersebut masih belum mengetahui dampak dan faktor yang akan merugikan dirinya sendiri, meskipun hal ini mengyangkut tentang kehamilan.

Kehamilan seharusnya menjadi sebuah berita yang membahagiakan, jika hadir pada mereka pasangan suami istri yang sudah melangsungkan perkawinan dan hal tersebut merupakan kabar baik yang dirindukan dan dinanti-nanti oleh pasangan suami istri dengan kehadiran si buah hati atau malaikat kecil yang menjadi penyejuk dalam kesehariannya. Namun hal tersebut akan berbeda jika menimpa meraka para remaja putri khususnya yang masih sekolah/kuliah dan belum melangsungkan proses perkawinan terlebih dahulu.

Bahkan kehamilan akan menjadi momok yang sangat menakutkan, yakni ancaman buat masa depan, bagi mereka yang belum menikah, dan akan menjadi kabar buruk yang sangat ditakutkan dan tidak diinginkan, faktor penyebab, diantaranya adalah karena keingintahuan yang sangat tinggi, biasanya bagi mereka yang masih ada di usia remaja, di karenakan pergaulan bebas, minimnya pengetahuan yang berkaitan dengan seks, karena kurangnya pendidikan tentang keagamaan, dan kurangnya perhatian dari kedua orang tua.

\section{b. Faktor Ekonomi}

Meningkatnya angka kawin muda dan permintaaan permohonan dispensasi perkawinan di Pengadilan Agama Kabupaten Bantaeng semakin tahun samakin banyak hal ini dipicu oleh rendahnya kemampuan ekonomi masyarakat, kondisi ekonomi masyarakat yang lemah menyebabkan orang tua tidak bisa menyekolahkan anaknya kejenjang yang lebih tinggi, para orang tua beranggapan bahwa menikahkan anaknya merupakan salah satu solusi untuk 
meringankan beban hidupnya keluarga, hal inilah yang menjadi alasan para pemohon (orang tua) sudah tidak sanggup lagi menjalani beban hiudp yang samakin hari kebutuhan semakin meningkat sehingga jalan terakhir para orang tua yakni menikahkan anaknya meskipun secara peraturan perundang-undangan tidak dibolehkan, maka dalam hal ini para pemohon (orang tua) meminta dispensasi perkawinan di pengadilan.

Berdasarkan data yang masuk di pengadilan Agama Kabupaten Bantaeng kasus yang terjadi dalam persoalan perkawinan dibawah umur semakin banyak hal yang menyebabkan salah satu faktornya adalah kemiskinan, kemiskinan merupakan penyebab orang tua mengawinkan anaknya merka merelakan anak perempuannya diminta untuk berhenti bersekolah untuk sekedar membantu orang tua, dengan demikian anak perempuan yang dikawinkan tersebut orang tua berharap beban hidup mereka berkurang.

\section{c. Faktor Pendidikan}

Rendahnya tingkat pendidikan cenderung melakukan aktivatas sosial ekonomi yang turun temurun tanpa adanya petanggung jawaban. Akibat lanjutnya produktivitas kerjanyapun sangat rendah sehingga tidak mampu memenuhi kebutuhan hidupnya secara memadai. Sehingga pemohon memiliki alasan untuk menikahkan anaknya, Karena terkadang seorang anak perempuan memutuskan untuk dimenikah diusia yang tergolong muda. Pendidikan dapat mempengaruhi seorang wanita untuk menunda usia untuk menikah karena banyak hal yang harus ditata baik ekonomi mentalitas anak itu sendiri . Makin lama seorang wanita mengikuti pendidikan sekolah, maka secara teoritis makin tinggi pula usia kawin pertamanya. Seorang wanita yang tamat sekolah lanjutan tingkat pertamanya berarti sekurang-kurangnya ia menikah diusia yang dini, namun hal ini yang tidak ada dalam pemikiran orang tua anak, pemikiran-pemikran untuk menikahkan anaknya diusia dini cukup melekat pada masyarakat pedesaan, meraka tidak bisa melihat perempuan bekerja diluar rumah sehingga perempuan selalu ditempatkan di dapur saja, hal inilah yang menyebabkan pemohon bertujuan untuk menikahkan saja dan meraka para orang tua lebih baik meminta dispensasi perkawinan ke Pengadilan Agama Kabupaten Bantaeng.

Pada dasarnya orang tua masih belum paham pentingnya pendidikan, manfaat dari sebuah pendidikan dan tujuan dari pendidikan sehingga para orang tua yang secara materi kurang mampu ingin ssegera menikahkan anaknya walupun secara umur dia belum diperbolehkan oleh Undang-Undang Nomor 1 Tahun 1975 Tentang Perkawinan dalam pasal 7 (1), hal itu biasanya 
terjadi setelah remaja lulus SMP atau Belum. Mereka mengangap Pendidikan itu tidak penting. Bagi masyarakat pedesaan, lulus SD saja sudah cukup, padahal anak-anak mereka memiliki keginginan untuk melanjutkan pendidikan kejenjang ke lebih tinggi.

Dalam sudut pandang masyarakat yang tidak mampu untuk melanjutkan pendidikan khususnya orang miskin, dalam hal ini orang tua pemohon, mereka menganggap ketika anak sudah baliq (Dewasa) secara agama islam, maka bagi mereka sudah selayaknya dinikahkan untuk mengurai beban keluarga.

\section{Faktor-Faktor Yang Mempengaruhi Dasar Pertimbangan Hakim Dalam Mengabulkan Dispensasi Perkawinan}

Dispensasi usia perkawinan terjadi apabila adanya permohonan dari wali salah satu pihak laki-laki dan perempuan yang belum cukup usia untuk melakukan perkawinan dalam Undang-Undang Nomor 1 Tahun 1974 tentang Perkawinan, bagi laki-laki minimal berusia 19 tahun dan bagi wanita minimal berusia 16 tahun, meminta izin ke Pengadilan Agama.

Faktor-faktor yang mempengaruhi dasar pertimbangan hakim dalam mengabulkan dipensasi usia perkawinan yaitu hakim tidak terikat dengan hukum positif. Hakim diberi kesempatan untuk melakukan penemuan hukum dengan pertimbangan bahwa apabila undang-undang menetapkan hal-hal tertentu untuk peristiwa tertentu, berarti peraturan itu terbatas pada peristiwa tertentu. Larangan untuk menikah di bawah umur secara eksplisit tidak ditemukan di dalam Undang- Undang Perkawinan. Meskipun telah diatur batasan usia persyaratan perkawinan, namun pada tingkat praktik penerapannya bersifat fleksibel. Artinya, jika secara kasuistis memang sangat mendesak atau keadaan darurat demi menghindari kerusakan/ mafsadah harus didahulukan mempertahankan kebaikan/maslahah maka kedua calon mempelai harus segera dikawinkan.

Hakim tidak hanya berpacu pada undang-undang karena apabila hakim menggunakan pendekatan metodologi dalam pengkajian hukum Islam (fiqh) mengenai permohonan usia kawin, perlu dipertimbangkan maslahat mursalah (metode ijtihad dalam hukum Islam yang berdasarkan kemaslahatan umum). ${ }^{11}$

${ }^{11}$ Zainuddin Ali, Hukum Perdata Islam di Indonesia (Jakarta: Sinar Grafika, 2006), h. 14 
Hakim mengedepankan konsep maslahat murshalah yaitu pertimbangan kebaikan dan menolak kerusakan dalam masyarakat serta upaya mencegah kemudharatan. Maslahat mursalah itu adalah maslahah yang hakiki dan bersifat umum, dalam arti dengan dikabulkannya dispensasi usia perkawinan terhadap anak yang belum cukup usia untuk melakukan perkawinan dapat diterima oleh akal sehat bahwa ia betul-betul mendatangkan manfaat bagi kedua calon mempelai serta keluarga masing-masing mempelai dan menghindarkan mudharat dari perbuatan- perbuatan dosa yang dilakukan pasangan muda-mudi diluar perkawinan. Yang dinilai akal sehat sebagai suatu maslahah yang hakiki betul-betul telah sejalan dengan maksud dan tujuan syara' (membangun rumah tangga yang utuh) dalam menetapkan setiap hukum, yaitu mewujudkan kemaslahatan bagi umat manusia. Yang dinilai akal sehat sebagai suatu maslahah yang hakiki dan telah sejalan dengan tujuan syara' dalam menetapkan hukum itu tidak bertentangan dengan dalil syara' yang telah ada, baik dalam bentuk nash Al-Quran dan sunnah, maupun ijma' ulama'terdahulu. Maslahah mursalah itu diamalkan dalam kondisi yang memerlukan dalam hal ini hakim mengabulkan dispensasi usia perkawinan, yang seandainya maslahatnya tidak diselesaikan dengan cara ini, maka umat akan berada dalam kesempitan hidup, dengan arti harus ditempuh untuk menghindarkan umat dari kesulitan dalam penyaluran nafsu biologis sehingga terhindar dari perangkap perbuatan mesum diluar pagar pernikahan.

\section{a. Pertimbangan Hakim}

Penekanan pada asas kepastian hukum lebih bernuansa pada terciptanya keteraturan dan ketertiban dalam masyarakat. Penekanan pada asas keadilan, berarti hakim harus mempertimbangkan hukum yang hidup dalam masyarakat, yang terdiri atas kebiasaan dan ketentuan hukum yang tidak tertulis. Dalam hal ini harus dibedakan rasa keadilan menurut individu, kelompok, dan masyarakat. Selain itu, keadilan dari suatu masyarakat tertentu, belum tentu sama dengan rasa keadilan masyarakat tertentu yang lainnya. Jadi dalam pertimbangan putusannya, hakim harus menggambarkan hal itu semua, manakala hakim memilih asas keadilan, misalnya, sebagai dasar untuk menjatuhkan putusan. Penekanan pada asas kemanfaatan lebih bernuansa kepada segi ekonomi, dengan dasar pemikiran bahwa hukum itu ada untuk manusia. Sehingga tujuan hukum itu harus berguna bagi masyarakat banyak. ${ }^{12}$

Dalam permohonan dispensasi usia perkawinan, hakim lebih

12 Zainuddin Ali, Hukum Perdata Islam di Indonesia (Jakarta: Sinar Grafika, 2006), h. 135. 
mengedepankan asas kemanfaatan hukum. Dari sudut pandang sosiologi hukum, tujuan hukum dititik beratkan pada segi kemanfaatan. Asas kemanfaatan hukum lebih melihat kepada manusia dan bukan manusia ada untuk hukum. Orang tua yang mengajukan permohonan dispensasi ke Pengadilan Agama dikabulkan oleh hakim karena dianggap lebih besar manfaatnya dari pada tidak dikabulkan. ${ }^{13}$

Seperti dalam Penetapan No 25/Pdt.P/2013/PA.Btg. Dalam kasus ini, pemohon adalah orang tua dari anak laki-laki yang berumur 16 tahun. Pemohon berencana untuk melangsungkan perkawinan tetapi Kantor

Urusan Agama Kecamatan Sinoa, KUA menolak mengawinkan karena belum cukup umur menurut Undang-Undang Nomor 1 Tahun 1974 tentang Perkawinan yaitu belum mencapai umur 19 tahun. Anak laki-laki dari pemohon ini telah berpacaran dengan seorang perempuan yang sudah saling kenal dan telah lama saling mencintai. Anak pemohon secara pisik dan secara hukum agama Islam telah dewasa dan dapat membantu ayahnya bekerja di Ladang. Bagi anak laki-laki pemohon dengan calon istrinya tidak ada halangan untuk menikah. Menimbang bahwa berdasarkan keterangan saksi-saksi tersebut dihubungkan dengan dalil permohonan pemohon, maka majelis hakim menilai bahwa anak pemohon dipandang layak untuk dinikahkan dengan calon istrinya untuk menghindari hal-hal yang tidak diinginkan, karena keduanya sudah sama-sama suka dan saling mencintai. ${ }^{14}$

Dalam hal seperti ini, hakim tidak kuasa menolak untuk memberikan dispensasi usia perkawinan karena ditakutkan jika permohonannya ditolak akibatnya lebih besar. Jadi, demi menghindari kerusakan/ mafsadah harus didahulukan mempertahankan kebaikan/maslahah maka kedua calon mempelai harus segera dikawinkan.

Hubungan kedua anak yang dikatakan sudah saling menyukai dan saling mencintai ditakutkan akan bermuara ke jalan yang salah. Keinginan orang tua yang sudah ingin menikahkan anaknya dan anak yang sudah mempunyai keinginan atau hasrat yang tinggi dalam membangun rumah tangga namun tersendat keinginannya karena batas usia menurut Undang-Undang

${ }^{13}$ Wawancara dengan hakim Pengadilan Agama Kelas 2B Bantaeng Provinsi Sulawesi Selatan, Muhammad Arief Ridha, pada tanggal 21 Juli 2016.

${ }^{14}$ Data sekunder, Arsip Pengadilan Agama Bantaeng, Penetapan Nomor: 25/Pdt.P/2013/PA.Btg. diambil pada tanggal 21 Juli 2016 
Perkawinan belum mencukupi umur untuk melakukan perkawinan padahal kedua orang tua sudah merestui hubungan.

Dengan diberikannya dispensasi kawin oleh Pengadilan Agama, maka keabsahan hubungan dan status perkawinan mereka sah dihadapan hukum dan di mata masyarakat. Apabila permohonan dispensasi kawin tidak dikabulkan, maka ditakutkan terjadi dampak yang luar biasa, misalnya si anak nekat melakukan hubungan suami istri kemudian hamil terlebih dahulu sebelum adanya perkawinan.

Hal ini akan menjadi aib bagi keluarga. Keluarga akan mendapat hukuman dari lingkungan sosial berupa gunjingan-gunjingan yang tercela. Di mana orang tua tidak tahu menjaga anak mereka sehingga anaknya bisa hamil sebelum kawin. Bagi si anak yang telah hamil terlebih dahulu akan mendapat guncangan atas apa yang terjadi padanya. Mendengar gunjingan-gunjingan tercela atas dirinya mungkin membuat psikisnya sedikit terganggu apalagi di usianya yang masih labil.

Di usianya yang masih labil mendapat guncangan, ditakutkan si anak nekat menggugurkan anak yang telah dikandungnya. Selain mendapat dosa yang sudah berlipat juga akan berakibat pada nyawanya dan nyawa si calon bayi. Selain itu,hukuman pidana juga bisa dikenakan karena telah menggugurkan jiwa seorang anak yang masih dalam kandungan.

Untuk menghindari hal-hal tersebut, maka hakim sebagai bagian dari aparat penegak dan praktisi hukum harus lebih mempertimbangkan kemanfaatan hukum dalam mengabulkan permohonan dispensasi usia perkawinan.

Berdasarkan kasus Penetapan No. 25/Pdt.P/2013/PA.Btg, hakim tidak terikat dengan hukum positif. Perkara dispensasi perkawinan merupakan perkara yang besifat volunteer. Dengan kata lain, undang- undang menilai putusan yang sesuai dengan gugat permohonan adalah penetapan, yang lazim juga disebut beschikking dalam arti luas. Perkara dispensasi hanyalah untuk mendapatkan hak dari pemohon sehingga hanya membutuhkan keterangan saksi dari pihak-pihak yang benar-benar mengetahui keadaan pemohon.

Dengan demikian, maka berdasarkan Penetapan No. 25/Pdt.P/2013/PA.Btg., hakim tidak terikat pada hukum positif. Dalam mengabulkan penetapan ini, hakim tidak hanya berpacu pada Undang-Undang Perkawinan mengenai batasan usia kepada pihak laki-laki berusia 19 tahun dan pihak wanita 16 tahun tetapi hakim bersifat progresif di mana hakim lebih mendahulukan kepentingan manusia yang lebih besar daripada menafsirkan hukum dari sudut logika dan peraturan. 
Ruslan, S.Ag. Hakim Pengadilan Agama menambahkan Hakim tidak boleh hanya berpacu pada undang-undang yang mengatur batasan usia meskipun meskipun seorang anak yang belum cukup umur ingin melakukan perkawinan tetapi mereka sudah mampu mengurus rumah tangga hanya usianya yang belum mencukupi sesuai

ketentuan dalam undang-undang perkawinan maka mereka secara syarat bathin sudah siap karena haram hukumnya melakukan perkawinan jika syarat lahiriahnya saja yang terpenuhi.

Hakim tidak kuasa menolak keadaan pemohon karena hakim lebih memperhatikan kemanfaatan hukum bagi pembangunan masyarakat dan mengedepankan masalah kemaslahatan demi kepentingan umum. Dikhawatirkan lebih besar mudharatnya jika permohonan dispensasi usia perkawinan ditolak.

\section{PENUTUP}

Prosedur pelaksanaan Dispensasi Kawin pada Pengadilan Agama Bantaeng sama dengan prosedur berperkara pada umumnya. Permohonan Dispensasi Kawin diajukan oleh orang tua pria mupun wanita kepada pengadilan agama yang mewilayahi tempat tinggalnya. Kemudian berkas perkara diperiksa oleh Majelis Hakim, ketua majelis memulai pemeriksaan dengan pertanyaan pertanyaan yang diajukan kepada pemohon, anak pemohon dan calon anak pemohon secara bergantian. Kemudian Ketua Majelis

melanjutkan pemeriksaan bukti surat dan sidang di skors. Setelah musyawarah selesai, skors dicabut dan pemohon dipanggil kembali masuk ke ruang persidangan, kemudian dibacakan penetapannya.

Terdapat beberapa faktor yang menjadi penyebab diajukan dispensasi perkawinan antara lain karena Faktor Hamil sebelum melangsungkan perkawinan, Faktor Ekonomi, dan Faktor Pendidikan. Dasar pertimbangan hakim dalam mengabulkan dipensasi usia perkawinan yaitu hakim tidak hanya berpacu pada Undang - Undang, disinilah diperlukan ijtihad hakim dalam menetapkan sesuatu berdasarkan maslahat mursalah. Hakim harus memperhatikan dampak yang akan ditimbulkan oleh sesuatu yang telah ditetapkannya. 


\section{DAFTAR PUSTAKA}

Aj-Jahrani Musfir, Poliga mi da ri Berba ga i Persepsi . Jakarta: Gema Insani Press, 2002.

Departemen Agama,RI, Alqur'an dan Terjemahnya.

Undang-Undang Perkawinan \& Kompilasi Hukum Islam di Indonesia. Jakarta: Direktorat Jendral Pembinaan Kelembagaan Agama Islam, 1998/1999.

Rofiq M.A, Ahmad, Hukum Isla $m$ di Indonesia. Jakarta: PT. Raja Grafindo Persada, 1998.

Basyir, Ahmad Azhar. Hukum Perkawinan Islam. Yogyakarta: Fakultas Hukum UII, 1977.

Sitompul, Anwar. Kewenangan Dan Tata Cara Berperkara Di Pengadilan Agama. Bandung: Armico.

Arto, Mukti. Praktek Perkara Perdata Pada Pengadilan Agama. Yogyakarta : Pustaka Pelajar, 2007.

Departemen Agama RI, Bahan Penyuluhan Hukum. Jakarta: Direktorat Jendral Pembinaan Kelembagaan Agama Islam, 1999/2000.

Wawancara dengan hakim pengadilan agama kelas 2 B Bantaeng Bapaj Ruslan S.Ag. pada tanggal 21 Juli 2016

Ali, Zainuddin. Hukum Perdata Islam di Indonesia. Jakarta: Sinar Grafika.

Wawancara dengan hakim Pengadilan Agama Kelas 2B Bantaeng Provinsi Sulawesi Selatan, Muhammad Arief Ridha, pada tanggal 21 Juli 2016.

Data sekunder, Arsip Pengadilan Agama Bantaeng, Penetapan Nomor: 25/Pdt.P/2013/PA.Btg. diambil pada tanggal 21 Juli 2016. 